\title{
JELENTÉSEK A FRONTVONALBÓL - VERSENY ÉS VERSENYKÉPESSÉG VÁLLALATI MÉLYINTERJÚK TÜKRÉBEN
}

\begin{abstract}
A GKI Gazdaságkutató Zrt. 2007 folyamán a Gazdasági Versenyhivatal Versenykultúra Központja megbízásából végzett kutatást annak vizsgálatára, hogy kimutatható-e összefüggés a nemzetgazdasági ágazatokban folyó verseny erôssége és az ágazatok vállalatainak versenyképessége között. A cikk elsố részében (Vezetéstudomány, 2008. június) a GKI régebbi vállalati felméréseinek a kutatás szempontjait szolgáló átvizsgálását mutatta be. Ennek során azt találták, hogy gyenge kapcsolat van a válaszadó vállalatok versenyképessége és az általuk tapasztalt verseny erôssége között. A második részben a kutatás során folytatott empirikus kutatás tapasztalatait tárja a szerzố az Olvasó elé. ${ }^{1}$
\end{abstract}

\section{Kulcsszavak: versenyképesség, versenyképesség-kutatás, Magyarország}

Az adatgyưjtést azzal kezdtük, hogy néhány iparágban vállalati interjút készítettünk a versenyviszonyokról és az azokhoz való alkalmazkodásról. A kiválasztott ágazatok olyanok voltak, ahol a verseny korábbi ismereteink szerint nagyon éles:

- nem fém ásványi termékek gyártása: 6 cég,

- építőanyag-kereskedelem: öt cég,

- ingatlanügyletek: hat cég,

- szoftverfejlesztés és tanácsadás: öt cég.

A sajátos versenypozíciójuk miatt kizártuk a multinacionális nagyvállalatokat és a mikrovállalkozásokat. Olyan cégeket kerestünk, amelyek annak a piacnak, ahol múködnek jelentôs, de nem domináns szereplôii. A vállalatok kiválasztása véletlenszerúen történt.

A nem fém ásványi termékek gyártása (lényegében a régi építóanyag-ipar kategóriának megfelelő tevékenységek) területén a piacot elsôsorban Magyarország jelenti, mert ezek a termékek többségükben érzékenyek a szállítási távolságra. A vevớk jellege szerinti piacot a lakosság és a továbbfelhasználó vállalatok jelentik. A vállalatok fó vásárlói a vállalkozások, közintézmények. A téglagyártó termékeit inkább a lakosság veszi. A releváns piaci szereplók száma 4-40 között ingadozik, az igazi veszélyt a kiemelkedő nagyságú és tốkeerejú vállalatok és a multik jelentik a piacon: az erófölénnyel, a tôkeerővel, a marketingkapacitással. A verseny tárgya a cégek megítélésében különböző. Négy cég szerint az árakban és a kapcsolódó szolgáltatásokban versenyeznek versenytársaikkal. A kapcsolatok is fontosak a munkák megszerzésénél. Két cég véleménye ettôl eltérő. A betongyártó cég szerint az árakban nincs verseny, mert mindegyik nagyobb vállalat közel azonos fejlettségi szinten van. A téglagyártó cég szerint pedig olyan alacsony a kereslet, hogy az önköltséghez közeli szinten kell értékesíteniük. Ennél alacsonyabbra már nem tudnak menni. Csak a technológia, a termékminőség és a magasabb esztétikai érték elóállításával tudnak versenyezni.

Az építô- és építőanyag-ipar területén dolgozó társaságok többsége extenzív, piacnövelő stratégiát folytat. A forgalom növelésével igyekszik jövedelmezőségét szinten tartani. Ennek a kereslet szab gátat, mert úgy túnik, kapacitásaik (humán és eszköz) elbírják az évi 10-20\%-os növekedést.

A tisztességtelen verseny eszközeinek széles palettája gyúlt össze.

- A piacvezetô és piacot uraló cég szerződésben kötelezi nagyobb partnereit, hogy a maximális jutalék eléréséhez egy adott funkcióra alkalmas termékból az ő termékein kívül csak egyetlen más gyártó által elóállított terméket forgalmazzon. Ezáltal a kereskedô döntése, hogy ki lesz a másik szereplö, akit beenged a piacra. 
- Az önkormányzati megrendelések esetében a korrupció és a baráti kapcsolatok jelentôss szerepe játszanak.

- „Meg kell venni a munkát” - mondta eufemisztikusan az interjúalany. Ez a megrendelés megszerzéséhez szükséges csúszópénzek kifizetését jelenti „zsebbe”, a döntéshozóknak. Minél nagyobb a megrendelés, annál nagyobb hányadot kérnek így. Az egyes autópálya-szakaszokra ún. lobbi csapatok vannak, amelyek a vámot beszedik. A önkormányzatokból kiválnak emberek és árulják a kapcsolataikat.

- Gyakori a tervezók jutalmazása abban az esetben, ha az ô termékeikre készítik el a tervet. Bá ez jogszabályellenes (nem szerepelhet a tervben konkrét gyártó, illetve márkanév megjelölése), az építési engedélyezési eljárás során ezt senki sem kéri számon a tervezôtốl.

- Egyes vállalatok megfenyegetik a vevóiket a kapcsolt termékek korlátozásával: megvonják tốlük speciális termékeket, amennyiben nem tốlük vásárolják az alapanyagokat.

- Jellemzó a piacra a számlaadás elmulasztása és a vámcsalás is, de ezek ma már kevésbé elterjedtek és ritkán alkalmazottak.

Az építóanyag-kereskedelemmel foglalkozó vállalatok is többségükben hazai piacon múködnek, kivéve a faipari kereskedelemmel foglalkozókat. A faipar célpiacai: Olaszország, Ausztria, Németország, Hollandia, Görögország. A vevók szerint az építőanyag-kereskedók 80\%-ban a lakosság felé, a faipari vállalkozások többségében a vállalatoknak értékesítenek. A versony tárgya és terepe változatos az építónnyag-ipari cégek tárgya és terepe változatos az építoanyag-ipari cégek esetében. Az ánersenyt egyik cég sentét ny nyeznek. Az építőanyag-kereskedő́k fizetési politikáj vagy az azonnal fizetés, vagy a 8-30 napos, határidố fizetés. Aki meg tudja tenni, mert bőven van vevője az nem engedi meg a milliós tartozásokat. Pár alkalom után nem áll szóba a vevôvel. Ezzel együtt a szakmát erôsen sújtják az építóipari körbetartozások.

Gondot jelent a pályázatok utófinanszírozás is, illetve a beruházások indítása úgy, hogy a finanszírozás nem biztosított. A csődeljárás során kimentik a vagyonokat, és a vétlen vállalkoż futhat a pénze után. Pereik vannak folyamatban. A csődeljárásnak nincs konzekvenciája a cégvezetôkre. Másnap már az egyablakos rendszerben könnyen alapíthat egy új céget. Az államnak kellene rendet csinálnia, de nem nagyon tör magát. Az új jogszabály, hogy jelzálogot lehet bejegyeztetni a beruházásra, nem érvényesíthetô, mert ha ezt érvényesíteni akarják, nem kapják meg a megrendelést. A rendszer nem a tisztességes vállalkozókat védi.” (Interjúrészlet)

Az építóanyag-kereskedelem területén jellemzó forgalom volatilitása, aminek nem nagyon mennek tána a cégek a kapa, aminek nem nagyon mennek kozással meoszúnt a vámeljárás śs ez kai csat

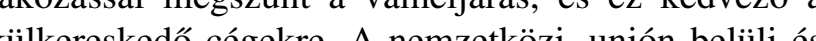
kilkereskedó cégekre. A nemzetkôzi, uniớn belüli és kívüli kereskedelemnél talán a különböző szintû́ országonkénti adózást lehetne megemlíteni, ami egyes versenytársaknak elônyt, másoknak hátrányt jelenthet. Az uniós pályázatokon való részvétel vagy a túl kicsi vállalatoknak vagy a multiknak kedvez, a közepesek kimaradnak belóle.

A tisztességtelen verseny módszerei az építőanyagereskedelemben:

- az építőfenyő fứrészárunál nagyon erốs a feketekereskedelem: vámpapírok szerint 30 köbméter van egy importárut hozó kocsin, a valóságban 40-45,

- nagyobb projekteknél kemény kenópénzeket kérnek,

- elófordul, hogy bizonyos cégek visszaélnek a termékek minőségével, feketén szerzik be azokat, és márkázottként adják el, sok esetben ismét feketén, számla garacke el, sok

- épitőanyag-kereskedő kis cég számla nélkül értékesít, teljesen nyíltan,

- technológia átvétele illetéktelenül,

- korrupció a hatósági engedélyek megszerzésében.

$A z$ ingatlanügyek piaca. Ezen a piacon magyar es külfoöldi tulajdonban levố cégek egyaránt szerepelnek, a verseny éles. A cégek vagy csak lakossági, vagy csak üzleti igényeket elégítenek ki, egy válaszadó volt, amelyik mindkét vevő́csoportnak dolgozott. Az ingatlanhasznosító számára azok a versenytársak az igazán veszélyesek, akik a környéken hasonló adottságú irodaházakat építenek. Azúj lakások építése piacón a multik ó́keerósségik és eróteljesebb reklámjuk mitt veszé-

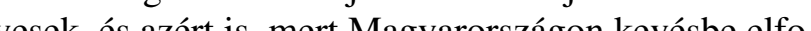
lyesek, es azêt is, nort Magyarországon kevésbe elfoadott, vagy nem ismert módszereket vezetnek be. Pl.

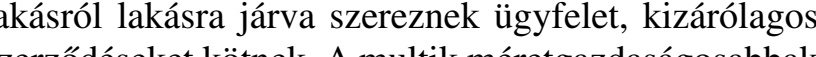
szerzôdéseket kötnek. A multik méretgazdaságosabbak könnyebben jutnak bankhitelhez. A verseny tárgya az ingatlanhasznosító piacán a kaució nagysága, a fuamidố meghatározása a szerzốdésekben, mert az árak kiegyenlítettek, a bérlớknek nyújtott szolgáltatások mennyisége és színvonala megegyezik. A közvetítók humán szolgáltatások minőségében és a marketingben versenyeznek leginkább, és van egy kismértékú árverseny is. Az ingatlanfejlesztốk a megfeleló típus (kisméretú, közepes árfekvésú, jó minőségú) ingatla kiválasztásával versenyeznek.

A tisztességtelen verseny módszerei a szakmában a következók:

A kizárólagosság kikötése a szerzôdésben nem jogszerú, illetve tisztázni kellene, hogy ki mit ért alatta. Nyugaton azt, hogy a megbízó egy közvetítôvel áll kapcsolatban, és az a közvetító együttmúködik a többiekkel a megbízás mielóbbi teljesítése érdekében, majd a jutalékon osztoznak. Nálunk azt, hogy az egy közvetítő magának akar mindent, akár az üzlet meghiúsulását is kockáztatva.

- A versenytársak úgynevezett szerződéses módon alkalmaznak munkatársakat, egy alacsony összeget tényleg le is papíroznak, de a nagy részét feketén fizetik ki a jutaléknak.

Néhány versenytárs nem valós dolgokat állít a hirdetésekben, például azt, hogy aki velük szerződik, az bekerül az ország összes adatbázisába (a multikhoz is), és irreálisan rövid idó alatt adja el az ingatlant, illetve saját erố nélkül is megszervezi hitelból a finanszírozást.

- Az esetek 30\%-ában előfordul, hogy egy vállalat piacvásárlási szándékkal veszteségesen (annyira olcsón) nevez be egy projektbe.

- A korrupció különbözó fajtái, illetve a túlszámlá zás elterjedtek ebben a piaci szegmensben.

A szoftverfejlesztéssel és tanácsadással foglalkozó cégek többsége hazai piacon múködik. A legtöbb cég dolgozik mind a lakosság, mind a vállalkozások, cég dolgozik mind a lakosság, mind a vállalkozáso közintézmenyek piacán. Vevơik száma 25-ig terje A mobilkommunikáció terén nincs kiélezett verseny. Á beszerzések inkább szubjektív döntésektôl függenek, így sokat számítanak a kapcsolatok. A cégek sokszor már meglévố rendszereiket akarjảk továbbfejleszten és nem szívesen cserélik le az egészet újra. A távoktat területén verseny a fejlesztések terén folyik, itt erôs multik jelenléte. A tanácsadó cégek a versenyben hoszszú távú ügyfélkapcsolatokkal és rugalmas szervezéssel igyekeznek helytállni.

A tisztességtelen verseny eszközei:

- A pályáztatás során pénzt juttatnak a kiírónak. „...egy bizonyos szinten túl a megrendelése 90\%-a korrupcióhoz köthetó. Nem jöhet létre az üzlet a döntéshozó magánjavadalmazása nélkül. Ez a jelenség a nagy cégeknek kedvez, és versen torzító hatâsú.'

A megrendeló kérése, hogy adott céget vegyene be alvállalkozónak.
- Igen elterjedt továbbá a kartellezés, a piaci szereplók (fóként a kis- és középvállalkozások) fennmaradásuk érdekében rákényszerülnek az olykor etikátlan együttmúködésre.

- Jelentős arányt képviselnek a körbeszámlázások. Amíg az Európai Unióban nem jön létre az egységes szolgáltatói piac (egységes adóterhek, egységes piaci feltételek stb.), addig elkerülhetetlen a feltételek - bár legális - mégis versenyt korlátozó módon történő kihasználása a cégek részéról. Ez a folyamat ugyancsak a multinacionális vállalatoknak kedvez, amelyek így nagyobb haszonra toknak kedvez, amelyek igy
tesznek szert, mint a kisebbek.

- Gondok vannak a közbeszerzési pályázatokkal. Az esetek többségében már a pályázat megjelenésének pillanatában tudni lehet, hogy „,kire írták ki a pályázatot”. Az interjúadó ezeket életképes összjátékoknak minősíti, amiben mindenki rész vesz, megszüntetni nem lehetséges.

- Egyes cégek nem tartják be a szabványosság követelményeit a fejlesztés során, így az általuk forgalmazott termék csak részben kompatibilis.

- A korrupció lehetősége a Vám- és Pénzügyőrség tevékenységében csökkenő mértékben, de továbbra is jelen van.

A négy ágazat egészéról a 22 interjú nem ad átfogó képet. Nem is ez volt a cél. Beleláttunk viszont egyes részpiacok múködésébe és sajátosságaiba. Ezeket a részpiacokat egy vagy két, esetleg három vállalat szemvegén keresztül szemlélhetjük.

Piacuk meghatározó szereplőinek száma nagyon változatos, a kereskedócégek esetében elérheti az ezer céget, de ez kivétel, a többieknél 2-60 közötti szereplố jelenik meg. A multinacionális cégek valamennyi részpiacon jelen vannak, és a kisebb vállalatok általában veszélyként élik meg jelenlétüket. A cégek számára a méret általában versenyelônyt jelent, kivéve a sajátos részpiacokat, ahol a speciális tudás megelózi a nagyságot. A multikkal való együttmúködés csak alvállalcozói for cégközi egyïrńkiödés nagyon kevés formúját mutatják fel. Egyeten lág ja már. Egyellon már meg is indult ezen az úton. A többiek a szakma rdekvédelmi szervezeti tagságig jutnak el

A piaci problémák, a korrupció, a nemfizetés, a körbetartozás leginkább az épitóiparra jellemzó, és valamivel kisebb mértékben az építőanyag-kereskedelemre. A tisztességtelen verseny eszközeinek palettája is itt a legszínesebb. A korrupció szinte mindenütt az állami és magánszféra találkozási pontjain jelenik meg. A nemfietés és körbetartozás kiindulópontja is sokszor az állam 
(hosszú áfa-visszafizetési határidók, beruházások utófinanszírozása stb.). Az ingatlanügyek és a szoftverfejlesztés területén kevesebb ilyen jellegú problémát jeleztek. A korrupció és az alacsony szintú üzleti morál nagyo megnehezíti az e területeken dolgozó cégek helyzetét.

A cégek felerészben vannak magyar és külföld tulajdonban. Vannak közöttük multinacionális vállalatlánchoz tartozó leányvállalatok. Sok a külföldi cégcsoporthoz tartozó az ingatlanfejlesztố és -hasznosító cégek között. Ezek a cégek tisztán külföldi tulajdonba vannak. Azố piaci helytállásuk könnyebb mint a haz tulajdonú cégeké, mert az anyavállalat tókéje, termákei,

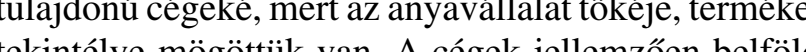
tekintely mogôn piacokon vanak jeln (kivéve a ja kulkereskedő céget), de nén nun legfóképpen Románia és Szlovákia felé.

Az elmúlt három év nem volt könnyú egyik cég számára sem. A súlyosbodó gazdasági helyzet nehézzé tette piaci helyzetük megórzését. Kevesen tudtak nagyobb árbevételt elérni és növelni jövedelmezôségüket. A helyzetre létszámcsökkentéssel, átszervezésse és kivárással reagáltak.

Mindegyik cég bizonyos területen (Európában, Magyarországon, a megyében stb.) versenyképesnek tartja magát, termékeit és szolgáltatásait is. Eszközhatékonyságukat és alkalmazottaik termelékenységét jónek je-

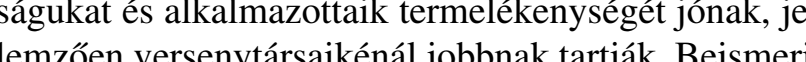
emzor vers ugyanakkor, hogy on, ano a nuaki fejlốes fontos

A versenyelónyök között kevesen említették az alacsony árat, sokkal inkább a minóséget, a jó vevớkiszogálást, a pontosságot, a magas színvonalú szaktudás. Inputokért ott van verseny, ahol hiány van: vagy az alapanyag kevés (fa, 2007-ben cement), vagy a képzett munkaerô. Szintén a hiány mozgatja a speciális beszállítók kivételezett helyzetét.

$\mathrm{Az}$ innováció technikai értelemben nem minden részpiacon egyformán fontos, pl. az ingatlanügyek területén alig. Nagyon jelentôs viszont az építố- és építóanyag-ipar minden megismert részpiacán és az IT-szektorban. A kereskedő́cégek esetében a és az tingmódszerek és a vállalatszervezés területén megvatingmódsuló innoveréció a jelentốs.

Az EU-csatlakozás ott nem hatott a piacra, ahol helyi kis piacról van szó, vagy ott, ahol már korábban is nyitott piac volt. Bár megállapították a cégek, hogy a csatlakozás elsősorban a multiknak kedvezett, azonban nem elsősorban a verseny élesedése a csatlakozás legfontosabb hatása, hanem új szabályok, esetleg új lehetôsége megjelenése, más szemlélet és kultúra kibontakozása. Természetesen sok probléma is van az uniós szabályok illeszkedésében, ismeretében és alkalmazásában.

\section{Versenykép 2007 végén}

\section{a vállalati felmérés eredményei}

A kutatás utolsó fázisában friss, immár célirányos vállati felmérést készítettünk a versenyintenzitás és a versenyképesség összefüggésére koncentrálva. Az alkalmazott módszer most is postai úton kiküldött, önkitöltỡs kérdőivvel operáló felmérés volt. A kitúzött határidôre összesen 1271 értékelhetố válasz érkezett, szerencsés módon olyan eloszlásban, hogy minden korábban vizsgált ágazat most is külön elemezhetố volt.

A mintavételi keret meghatározásának kiindulópontja - hasonlóan a korábbi felmérésekhez - most is a Központi Statisztikai Hivatal által összeállított, a jogi személyiségú vállalatokat tartalmazó listája volt. A keretból töröltük - sajnalatosan egyenlótlen versenyhelyzetük miatt - a 10 fó alatt foglalkoztató cégeket. Most sem szerepeltek a vizsgált szektorok közöt a pénzügyi szolgáltatások, a közigazgatás, a kötelezố társadalombiztositás, az egészségugy és szociális ellátás. A mintavételi keret elemeibő́l - a nemzetgazdasági ágak és a foglalkoztatott lêtszám alapjann képzett csoportok szerinti - arányos rétegzés mellett válaszlottuk ki a véletlen mintát. A minta elemszáma 7000 volt. A válaszadási arány $18 \%$-os, ami kiemelkedóen jó a hasonló vallalati kutatások hazai gyakorlatában. A felmérés során válaszadó cégek reprezentálják - foglalkoztatási szempontból - az alapsokaság 7,4\%-át.

A válaszmintában a mikro- (azaz 20 fô alatt foglalkoztató) vállalatok alul-, a közepes méretú (azaz az 51 és 250 fố között foglalkoztató) és a nagyvállalatok kissé túlreprezentáltak. A minta belsô szerkezetének ez a „hiányossága”, azaz a valóságos arányoktól való eltérése az alkalmazott elemzési technikákkal jórészt korrigálható.

A felmérés során elemzett fóbb csoportok válaszmintabeli eloszlását az 1. táblázat foglalja össze.

A versenyképességi csoportok kialakítási módja a következő volt: a megfelelő kérdésre adott válaszok alapján sorba rendeztük a cégeket, az elsô helyre a legversenyképesebb termékstruktúrát felmutatót, az utolsó helyre a legkevésbé versenyképessel rendelkezôt tettük. E rangsor alapján négy, megközelítóleg azonos elemszámú csoportba rendeztük a válaszadô állalkozásokat.

\section{A verseny intenzitása}

A piaci helyzet elsó jellemzójeként áttekintettük az exporthányadok alakulását. A válaszadók átlagosan 19\%-ot jeleztek. A méret szerinti bontás azt mutatta, hogy az 51 és 250 fó közôtti középvállalatok árbe-

Forrás: GKI Zrt. felmérése

\begin{tabular}{|l|c|c|c|}
\hline \multicolumn{1}{|c|}{ Csoportosító ismérv } & Kategóriák & $\begin{array}{c}\text { A válaszadók } \\
\text { száma }\end{array}$ & $\begin{array}{c}\text { A válaszadók } \\
\text { megoszlása (\%) }\end{array}$ \\
\hline \multirow{3}{*}{ Tulajdonosi háttér } & Állami többségú & 95 & 8 \\
\hline \multirow{4}{*}{$\begin{array}{c}\text { Az export részaránya az } \\
\text { osszes árbevételból }\end{array}$} & Belföldi magán többségú & 955 & 79 \\
\cline { 2 - 4 } & Külföldi többségú & 160 & 13 \\
\hline \multirow{3}{*}{ Versenyképesség } & $0 \%$ & 659 & 64 \\
\cline { 2 - 4 } & $1-25 \%$ & 203 & 20 \\
\cline { 2 - 4 } & $26-50 \%$ & 54 & 5 \\
\cline { 2 - 4 } & $50 \%$ felett & 114 & 11 \\
\hline & 1. csoport & 210 & 25 \\
\cline { 2 - 4 } & 2. csoport & 210 & 25 \\
\cline { 2 - 4 } & 3. csoport & 210 & 25 \\
\cline { 2 - 4 } & 4. csoport & 208 & 25 \\
\hline
\end{tabular}

A táblázat helyes értelmezéséhez célszerú szem elốtt tartani, hogy nem minden cég volt besorolható minden

szempont szerint, így a kategóriák létszáma nem mindig adja ki a válaszadók teljes számát.

vételében volt a legnagyobb (24\%) a kivitel aránya, ezt a nagyvállalatok követték $20 \%$-kal. A tulajdonosi csoportok közül - nem meglepó módon - a külfold többségúek ugrottak ki (35\%), míg az állami többsé tulajdonban lévók körében szinte ismeretlen az export (3\%). Az első bontások nem sok meglepetést hoztak, középvállalatok és a külföldi többségi tulajdonban levôk voltak a legnagyobb exportőrök. Meglepő, hogy nagyvállalati exporthányad kisebb lett, mint a középvállalatoké, ez a nagy multicégek mintabeli hiányából fakadt.

A nemzetgazdasági ágak szerinti bontás sem okozott meglepetést. Ebból a szempontból az ipar (43\%) és a mezőgazdaság (17\%) emelhetố ki, a többi ágazatban $10 \%$ alatt volt a mutató. Ez nagyjából a valós helyzetet tükrözi, hiszen a magyar exporton belül az utóbbi években az áruexportaránya meghaladta a 80\%-ot. A mezógazdaśgon belïl az erd"̋azdaśgok jeleztek A $50 \%$ feeti expor berendezésýátás, valamint a jar berond vieli hayld Jelentos volt az ung axpor a viteli hányaddal. Jelentós volt még az export a ruházati iparban (61\%), valamint a kohászat és fénfeldolgozás ágazatban (55\%). A szolgáltatóágazatok közül kieme hető a közúti teherszállitás (13\%), a kutatás-fejlesztés (16\%). A „,valódi” szolgáltatásexporton belül dominánsak az idegenforgalmi, s jelentősek az egyéb üzleti és a szállítási szolgáltatások.

A versenyképességi csoportosítás teljes mértékben megfelelt a várakozásainknak. Az l. abra igazo ja azt a korábbi feltételezésünket, hogy a cég versenyképesséex exportpiaci szereplése között összefüggés van

A vállalatok döntő többsége erốs (azaz kiélezett

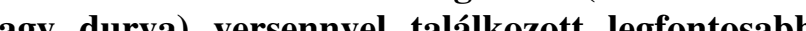
pia

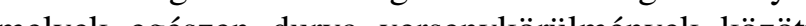

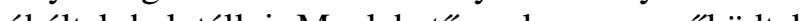
evés szereplős, mondhatni oligopolisztikus piacokon.

1. ábra

Az export aránya az értékesítésen belül 2007-ben, versenyképesség szerint Forrás: GKI Zrt. felmérése

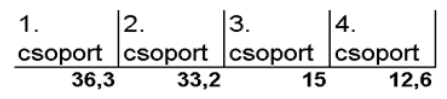

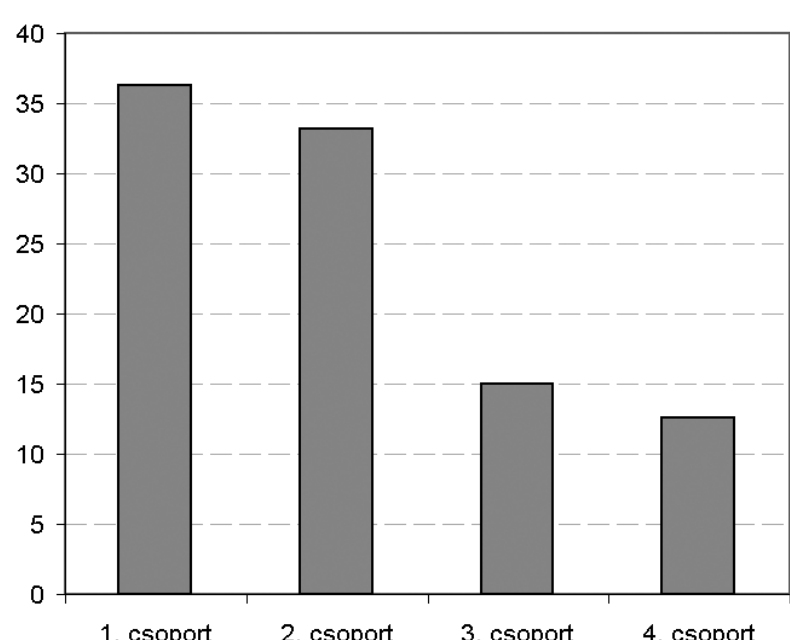


Versenyerốsség a legfontosabb piacokon, többségi tulajdonos szerint (megoszlás, százalék) Forrás: GKI Zrt felmérése

\begin{tabular}{|l|c|c|c|c|}
\hline & $\begin{array}{c}\text { Csak néhány szerepló } \\
\text { versenyez }\end{array}$ & $\begin{array}{c}\text { Átlagos erósségú a } \\
\text { verseny }\end{array}$ & Kiélezett a verseny & Durva a verseny \\
\hline Állami & 33 & 28 & 30 & 9 \\
\hline Belföldi magán & 7 & 26 & 47 & 20 \\
\hline Külföldi & 8 & 27 & 54 & 11 \\
\hline
\end{tabular}

A verseny erốssége a legfontosabb piacokon, nemzetgazdasági ágak szerin (megoszlás, százalék)

Forrás: GKI Zrt. feng

\begin{tabular}{|l|c|c|c|c|}
\hline & $\begin{array}{c}\text { Csak néhány szereplö } \\
\text { versenyez }\end{array}$ & $\begin{array}{c}\text { Átlagos erösségú a } \\
\text { verseny }\end{array}$ & Kiélezett a verseny & Durva a verseny \\
\hline Mezógazdaság & 10 & 56 & 24 & 10 \\
\hline Ipar & 11 & 29 & 50 & 10 \\
\hline Építóipar & 5 & 20 & 48 & 27 \\
\hline Kereskedelem & 6 & 18 & 50 & 26 \\
\hline Szállítás, távközlés & 16 & 9 & 56 & 19 \\
\hline Szolgáltatások & 17 & 31 & 38 & 14 \\
\hline
\end{tabular}

A méret szerinti bontásban nem volt igazán jelentôs eltérés az átlagos és kiélezett versenyt tapasztalók aŕnyában, a nagyvállalatok viszont a többieknél ritkábba nyában, a ná is igaz, de ốk kisebb arányban jeleztek kiélezett veris igaz, de ôk kisebb aranyban jeleztek kiéczett ver- $j$ senyt is, mint a többiek. Az állami cégek közül sokan tehát kevésbé voltak kitéve a versenynek, különösen a kemény versenynek, mint az egyéb cégek. Ezt az is alátámasztja, hogy egy késóbbi kérdésre az állami vállalatok jelezték a legkisebb arányban új versenytársak megjelenését piacaikon (2. táblázat).

Néhány szereplős piacot a legmagasabb arányban az energetikai szolgáltatók jeleztek (64\%) - ez a tény egybeesik a közfelfogással. Ebból a szempontból kiemelhetô még a szállítási ágazat (s azon belül is a közúti személyszállítás) és a szolgáltatás (azon beliil

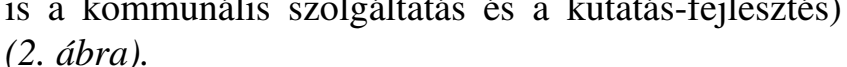

A másik szélsőséges esetet, azaz durva versenyt - nem meglepó módon - elsősorban az épittóipari és a kereskedő́cegek (s ez utóbbi szektoron belül fóként a jármúl- és üzemanyag-, valamint a fogyasztásicikkkereskedôk) jeleztek. Az építóipari cégekról a vállalati interjúkból tudjuk, hogy a durva verseny az ô körükben már nem is piaci, hanem bünügyi eszközökkel (korrupció, feketemunka stb.) folyik. Mindemellett a távközlési és a számitástechnikai szolgáltatók is az átlagosnál

yakrabban említették ezt a nagyon erôs versenyintentást (3. táblázat).

Durva verseny elsôsorban a hazai piacokon folyik a válaszadók szerint, amit fóként az említett ágazati sajasságok magyaráznak, tehát az, hogy a legerősebb verseny két olyan szektorban érzékelhetô, amelynek cégei lényegében csak a belföldi piacon jelennek meg. Az uniós csatlakozásra való felkészülés kapcsán korábban sokszor elhangzott a figyelmeztetés, hogy a

\section{A verseny erốssége a válaszadók szerint} 2. ábra

\section{A verseny eróssége a válaszadód
(megoszlás, százalék)} Forrás: GKI Zrt. felmérése

\section{csak néhány}

szereplö

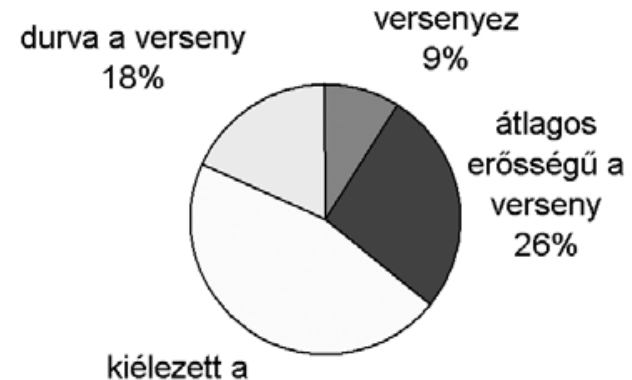

kiélezett a

verseny
$47 \%$ négy szabadság, különösen az áruk és szolgáltatások akik leginkább találkoztak új versenytársakkal - igaz, szabad áramlása a verseny élesedéséhez fog vezetni a nem nagy számúval, csak néhánnyal - mindkét piacon megszokott piacokon is. Ez nagyjából meg is történt. (4. táblázat).

A válaszadók 13\% -a találkozott nagyszámú új ver- A szolgáltatószektor és az építóipar találkozott a senytárssal a belföldi és $11 \%$-a az exportpiacokon. legkevesebb új versenytárssal. Belföldön a kereskedelNéhány új versenytárs jelent meg a cégek 43\%-ának mi cégek, exportpiacokon az iparvállalatok találkoztak belföldi és egyharmadának külföldi piacain. Úgy túnik, nagyobb arányban új konkurensekkel (5. táblázat).

az exportpiacokon okozott kisebb változást a csatlako- $\quad$ Erdekesen alakult a versenytársak fellépése az exportzás, ami valószínúleg annak köszönhetố, hogy a velünk orientáció szerinti metszetben. Úgy túnik, hogy a túlnyocsatlakozó országok exportőrrei is - a mieinkhez hason- móan belföldi piacra értékesító cégek mindenhol versenylóan - többnyire már jelen voltak az uniós piacokon erősödéssel találkoztak, de a nagy exportőrök kevésbé

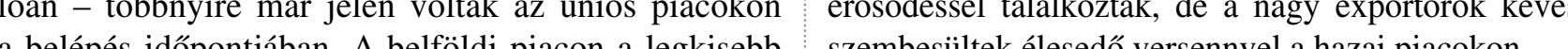
a belép idón és a kozepes cegek talalkoztak nagyobb arányban uj

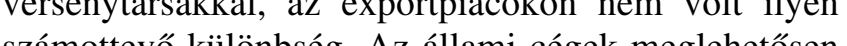

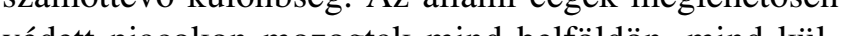
védett piacokon mozogtak nind belroldôn, mind külföldôn, kozulutu mondák a legtôbben, hogy nem tal koztak új versenytársakkal. A külföldiek voltak azok

Új versenytársak jelentek-e meg az uniós csatlakozás után? (megoszlás, százalék) Forrás: GKI Zrt. felmérése

\begin{tabular}{|l|c|c|c|c|c|c|}
\hline & \multicolumn{3}{|c|}{ A belföldi piacon } & \multicolumn{3}{c|}{ Az exportpiacokon } \\
\cline { 2 - 7 } & $\begin{array}{c}\text { Igen, nagy } \\
\text { számban }\end{array}$ & Igen, néhány & Nem & $\begin{array}{c}\text { Igen, nagy } \\
\text { számban }\end{array}$ & Igen, néhány & Nem \\
\hline \multicolumn{7}{|c|}{ Méret szerint } \\
\hline 20 fó alatt & 15 & 36 & 49 & 11 & 29 & 60 \\
\hline 20-50 fó & 10 & 49 & 41 & 11 & 32 & 57 \\
\hline $51-250$ fón & 16 & 44 & 40 & 11 & 37 & 52 \\
\hline 250 fó felett & 8 & 41 & 51 & 11 & 36 & 53 \\
\hline \multicolumn{7}{|c|}{ Fó tulajdonos szerint } \\
\hline Állami többségú & 9 & 38 & 53 & 0 & 19 & 81 \\
\hline Belföldi magán többségú & 14 & 42 & 44 & 12 & 32 & 56 \\
\hline Külföldi többségú & 10 & 47 & 43 & 6 & 45 & 49 \\
\hline
\end{tabular}

Új versenytársak jelentek-e meg az uniós csatlakozás után?

5. táblázat

(megoszlás, százalék)

\begin{tabular}{|l|c|c|c|c|c|c|}
\hline \multirow{2}{*}{} & \multicolumn{3}{|c|}{ A belföldi piacon } & \multicolumn{3}{c|}{ Az exportpiacokon } \\
\cline { 2 - 7 } & $\begin{array}{c}\text { Igen, nagy } \\
\text { számban }\end{array}$ & Igen, néhány & Nem & $\begin{array}{c}\text { Igen, nagy } \\
\text { számban }\end{array}$ & Igen, néhány & Nem \\
\hline Mezógazdaság & 18 & 39 & 43 & 9 & 42 & 49 \\
\hline Ipar & 14 & 42 & 44 & 14 & 44 & 42 \\
\hline Építóipar & 9 & 39 & 52 & 6 & 22 & 71 \\
\hline Kereskedelem & 17 & 51 & 32 & 11 & 33 & 56 \\
\hline Szolgáltatások & 8 & 37 & 55 & 5 & 18 & 77 \\
\hline
\end{tabular}

VEZETÉSTUDOMÁNY

A termékek versenyképessége nem egyértelmúen A azért elég markánsan kiemelkedik, hogy az elsố ersenyképességi csoportba tartozó cégek viszonylag evesebb új versenytárssal találkoztak mindkét piacon,

4. táblázat 


\section{A verseny tényezói}

A válaszadó cégek vitathatatlanul elsôsorban árversenyben álltak, 76\%-uk mondta ezt. A marketing. eszközök versenyszerepe jóval kisebb (összesen $60 \%$ említette), és még ennél is kevesebben (46\%) érezték a termékekben megtestesüló technikai tudás versenybeli szerepét. A minőségre taktikai okokból nem kérdeztünk rá egyenesen, ezt véleményünk szerint, a technológia és a múszaki tartalom hordozza magában. A válaszadók a kínálatból korlátozás nélkül több tényező́t is megjelölhettek, az összes válasz megoszlását a 3. ábra mutatja be.

3. ábra

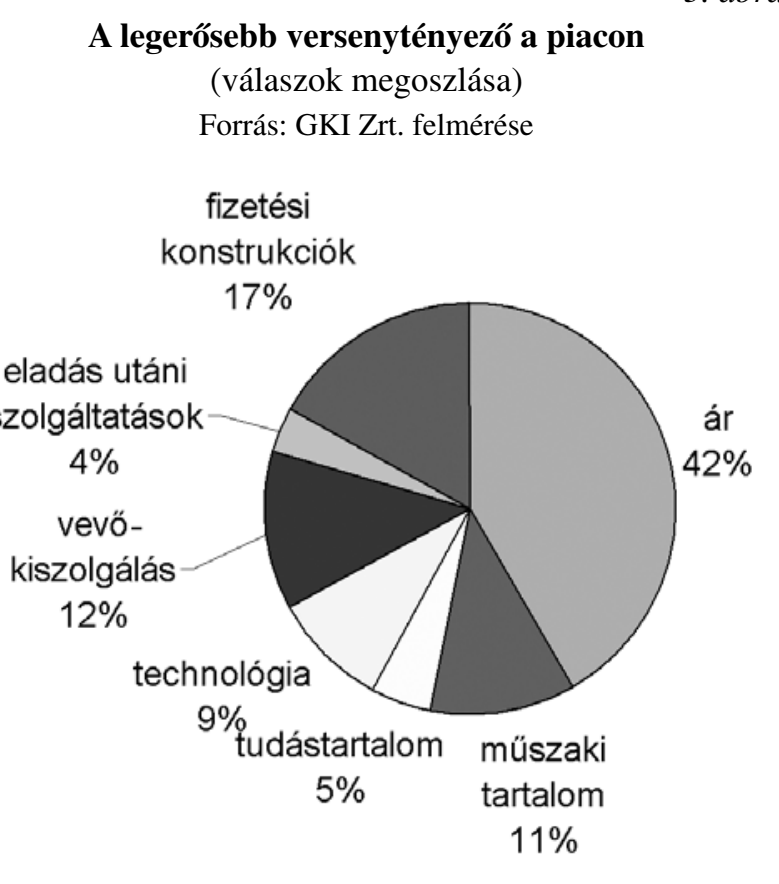

Az árverseny szerepe minden méretcsoportnál döntô volt. A nagyvállalati körben a technikát és a marke-

A legerốsebb versenytényezók a piacon, méret- és tulajdonosi csoportonként

6. táblázat

$$
\text { (említési arányok, százalék) }
$$

Forrás: GKI

\begin{tabular}{|l|c|c|c|c|c|c|c|}
\hline & 20 fó alatt & $\mathbf{2 1 - 5 0 ~ f o ́ ~}$ & $\mathbf{5 1 - 2 5 0 ~ f o ́ ~}$ & $\begin{array}{c}\mathbf{2 5 0} \text { fó } \\
\text { felett }\end{array}$ & $\begin{array}{c}\text { Állami } \\
\text { többs. }\end{array}$ & $\begin{array}{c}\text { Belf. m. } \\
\text { többs. }\end{array}$ & $\begin{array}{c}\text { Külf. } \\
\text { többs. }\end{array}$ \\
\hline Ár & 72 & 76 & 81 & 81 & 75 & 77 & 79 \\
\hline Múszzaki tartalom & 24 & 19 & 21 & 19 & 12 & 21 & 26 \\
\hline Tudástartalom & 11 & 9 & 7 & 10 & 4 & 9 & 11 \\
\hline Technológia & 12 & 18 & 19 & 21 & 17 & 16 & 22 \\
\hline Vevókiszolgálás & 19 & 24 & 24 & 25 & 27 & 21 & 32 \\
\hline Eladás utáni szolgáltatások & 5 & 7 & 8 & 5 & 4 & 7 & 8 \\
\hline Fizetési konstrukcí́k & 32 & 32 & 32 & 22 & 18 & 34 & 29 \\
\hline
\end{tabular}

VEZETÉSTUDOMÁNY
Versenytényezók a piacon, foó nemzetgazdasági áganként

(említési arányok, százalék)

Forrás: GKI Znt felmérése

\begin{tabular}{|l|c|c|c|c|c|c|}
\hline & Mezógazdaság & Ipar & Építóipar & Kereskedelem & $\begin{array}{c}\text { Szállít́s, } \\
\text { távoözlés }\end{array}$ & $\begin{array}{c}\text { Szolgáltatá- } \\
\text { sok }\end{array}$ \\
\hline Ár & 84,8 & 81,1 & 76,9 & 76 & 66 & 66,8 \\
\hline Múszaki tartalom & 1,9 & 25,4 & 30,4 & 13,7 & 19,1 & 18,6 \\
\hline Tudástartalom & 2,9 & 8 & 8,8 & 7 & 8,5 & 17,1 \\
\hline Technológia & 19 & 24,3 & 11 & 12,7 & 10,6 & 17,1 \\
\hline Vevókiszolgálás & 11,4 & 20,7 & 11 & 36,7 & 21,3 & 26,6 \\
\hline Eladás utáni szolgáltatások & 4,8 & 4,7 & 2,9 & 12,3 & 6,4 & 7 \\
\hline Fizetési konstrukciók & 38,1 & 26,6 & 38,5 & 33,7 & 31,9 & 22,1 \\
\hline
\end{tabular}

Versenytényezók a piacon, a verseny jellege szerin

8. táblázat (említési arányok, százalék)

Forrás: GKI Zrt. felmérése

\begin{tabular}{|l|c|c|c|c|}
\hline & $\begin{array}{c}\text { Csak néhány sze- } \\
\text { repló versenyez }\end{array}$ & $\begin{array}{c}\text { Átlagos erósségú a } \\
\text { verseny }\end{array}$ & Kiélezett a verseny & Durva a verseny \\
\hline Ár & 74 & 75 & 84 & 80 \\
\hline Mú́szaki tartalom & 19 & 24 & 25 & 11 \\
\hline Tudástartalom & 17 & 13 & 8 & 6 \\
\hline Technológia & 13 & 24 & 18 & 11 \\
\hline Vevókiszolgálás & 22 & 23 & 24 & 23 \\
\hline Eladás utáni szolgáltatások & 8 & 4 & 7 & 12 \\
\hline Fizetési konstrukciók & 19 & 25 & 34 & 47 \\
\hline
\end{tabular}

Verseny az erốforrások piacán, fố nemzetgazdasági ágankén

9. táblázat (említési arányok, százalék) Forrás: GKI Zrt. felmérése

\begin{tabular}{|l|c|c|c|c|c|c|}
\hline & $\begin{array}{c}\text { Mezógazda- } \\
\text { ság }\end{array}$ & Ipar & Építóipar & $\begin{array}{c}\text { Kereskede- } \\
\text { lem }\end{array}$ & $\begin{array}{c}\text { Szállítás, } \\
\text { távközlés }\end{array}$ & $\begin{array}{c}\text { Szolgáltatá- } \\
\text { sok }\end{array}$ \\
\hline A nyersanyagpiacon & 36 & 54 & 33 & 24 & 9 & 20 \\
\hline Az energiapiacon & 12 & 11 & 6 & 9 & 19 & 5 \\
\hline A pénzzügyi, fejlesztési források piacán & 32 & 23 & 22 & 34 & 21 & 29 \\
\hline A munkaerópiacon & 4 & 25 & 17 & 20 & 38 & 29 \\
\hline Nem versenyez eróforrásokért & 24 & 17 & 26 & 25 & 23 & 31 \\
\hline
\end{tabular}

erőforrások azonban ma sem állnak korlátlanul rendelkezésre. A válaszadók 76\%-a jelezte, hogy érzékel versenyt az erớforrások piacán. Leginkább a nyersanyagpiacon folyik verseny, ezt a pénzügyi, fejlesztési források vesebben az energiáért versenyeztek (9. táblázat).

\section{Versenyképesség}

A cégek versenyképességét két kérdéscsoporttal igyekeztünk megismerni. Egyrészt arról érdeklődtünk, hogy hogyan változott piaci helyzetük, másrészt arról, termékeik, szolgáltatásaik mekkora hannyada versenyképes.

\section{VEZETÉSTUDOMÁNY}


A piaci helyzet változása az EU-csatlakozás óta, méret- és tulajdonosi csoportonként

(említési arányok, százalék)

Forrás: GKI Zrt felmérése

\begin{tabular}{|c|c|c|c|c|c|c|c|}
\hline & 20 fó alat & $21-50$ fó & 51-250 fó & 250 fö felett & Állami többs. & Belf.m. többs. & Külf. többs. \\
\hline \multicolumn{8}{|c|}{ A belföldi piacon } \\
\hline Romlott & 32 & 28 & 31 & 18 & 15 & 33 & 19 \\
\hline Nem változott & 61 & 59 & 59 & 79 & 82 & 58 & 69 \\
\hline Javult & 7 & 13 & 10 & 4 & 3 & 9 & 12 \\
\hline \multicolumn{8}{|c|}{ Az exportpiacokon } \\
\hline Romlott & 23 & 18 & 17 & 18 & 12 & 19 & 16 \\
\hline Nem változott & 72 & 66 & 61 & 64 & 82 & 65 & 66 \\
\hline J & 6 & 16 & 23 & 18 & 6 & 16 & 18 \\
\hline
\end{tabular}

A piaci helyzet változása az EU-csatlakozás óta, fớ nemzetgazdasági áganként

11. táblázat (említési arányok, százalék)

Forrás: GKI Zrt. felmérése

\begin{tabular}{|l|c|c|c|c|c|c|}
\hline & Mezógazdaság & Ipar & Építóipar & Kereskedelem & Szállítás, távközlés & Szolgáltatások \\
\hline \multicolumn{7}{|l|}{ A belföldi piacon } \\
\hline Romlott & 26 & 29 & 28 & 38 & 42 & 19 \\
\hline Nem változott & 46 & 64 & 68 & 52 & 56 & 71 \\
\hline Javult & 28 & 7 & 4 & 10 & 2 & 10 \\
\hline \multicolumn{7}{|c|}{ Az exportpiacokon } \\
\hline Romlott & 23 & 22 & 16 & 17 & 48 & 6 \\
\hline Nem változott & 44 & 56 & 80 & 67 & 39 & 90 \\
\hline Javult & 33 & 22 & 4 & 16 & 613 & 4 \\
\hline
\end{tabular}

A felmérés idôszakában - 2007 szeptemberében már csaknem két és fél év telt el Magyarország uniós csatlakozása óta. Mint láttuk, a válaszadók jelentốs része nem találkozott azóta új versenytárssal, azonban mégis nagyobb arányban tapasztalták piaci helyzetük romlását (30\%), mint javulását $(9 \%)$ (10. táblázat).

A legnagyobb romlást az egészen kis vállalatok szenvedték el mindkét piacon. A belföldi piacon a nagyvállalatok vesztettek legkevésbé teret, az expontpiacok pericokon a középvállalatok pedig nég javítottak is pozícióikon. A tulajdonosi csopotok kozôt a kilfoldek voltak legsikeresebbek mindkét relációban (11. táblázat)

Egyedül a mezógazdasági vállalatok találták úgy, hogy piaci helyzetük mind belföldön, mind külföldön inkább javult a csatlakozás óta. Úgy túnik, a közös agrárpolitika védószárnya - minden megvalósítási zökkenó dacára - segített a hazai mezógazdasági cégeknek a versenyképességük javításában. A legnagyobb veszteséget pedig mindkét relációban a szállítás, távközlés szenvedte el (12. táblázat)

12. táblázat

A piaci helyzet változása

az EU-csatlakozás óta, exportrészarány szerint

(említési arányok, százalék)

Forrás: GKI Zrt felmérése

\begin{tabular}{|l|c|c|c|c|}
\hline & $\mathbf{0 \%}$ & $\mathbf{1 - 2 5 \%}$ & $\mathbf{2 6 - 5 0 \%}$ & $\begin{array}{c}\mathbf{5 0 \%} \\
\text { felett }\end{array}$ \\
\hline \multicolumn{5}{|c|}{ A belföldi piacon } \\
\hline Romlott & 31 & 30 & 32 & 17 \\
\hline Nem változott & 61 & 57 & 59 & 73 \\
\hline Javult & 8 & 13 & 9 & 11 \\
\hline \multicolumn{5}{|c|}{ Az exportpiacokon } \\
\hline Romlott & 16 & 22 & 11 & 21 \\
\hline Nem változott & 80 & 60 & 51 & 46 \\
\hline Javult & 4 & 18 & 38 & 33 \\
\hline
\end{tabular}

VEZETÉSTUDOMÁNY
A versenyképes termékek, szolgáltatások

aránya, méret- és tulajdonosi csoportonkén Forrás: GKI Zrt. felmérése

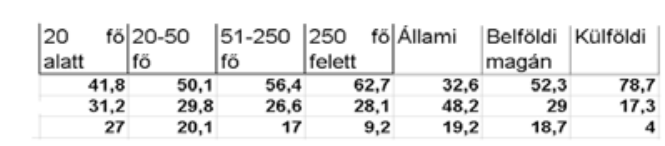

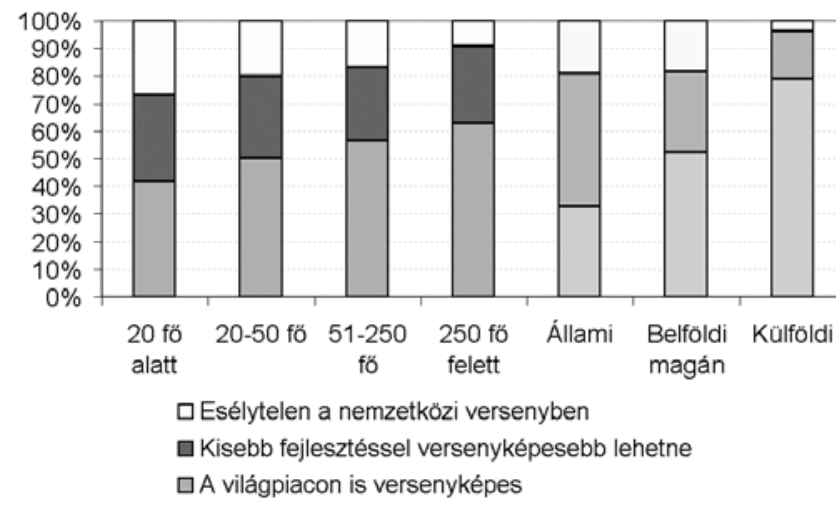

A válaszadó vállalatok kínálatának versenyképességét úgy mértük, hogy megkértük ôket, becsüljék meg, hogy termékeik, szolgáltatásaik mekkora hányada áll helyt a nemzetközi versenyben. Úgy gondoltuk, hogy az uniós csatlakozás révén kinyúl Uiaco lo lényehóben nem létezek oźn révén hich gében net nének bánillyen ánu beáramlâsának, tehát hazai piacon versenyképes, de nemzenkozi piacon esélytelen termék nem létezik. Alapvetôen más a helyzet a szolgáltatások esetében. Egyrészt, mert a szolgáltatások versenyének liberalizációja az unión belül fáziskésésben van az árukéhoz képest. Másrészt, mert a szolgáltatások jó része ugyanis ,non-tradable” jószág, azaz a világpiacon nem értékelődik. Ezek esetében - értelemszerúen - a nemzetközi szinthez mért versenyképesség nem, vagy csak nagyon nehezen értelmezhetô.

Az első figyelemre méltó megállapításunk az volt, hogy a fenti kérdésre a vállalatok 35\%-a nem adott választ. A legkisebb válaszadási arányok a 20 fó alatti kisvállalatoknál, az állami ć́geknél, az építtiiparb voltak. Ezeket még frettik is. Ezck a céck kerés

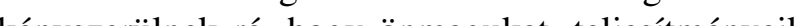

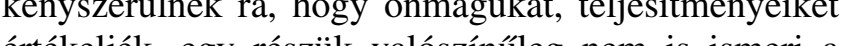
ertekeljék, egy részúk valószínuleg nem is ismeri a benchmarking módszercket. Kimong nom is isaszónak tartottuk, hogy a csak belföldre értékesítőknek 60\%-a válaszolt a kérdésre, míg a csak kismértékben exportálóknak is már 79\%-a, utána pedig tovább nốtt a válaszadók aránya. Ez sajnos arra utalt, hogy a hazai piacot sokan még mindig védett vadászmezőnek tekintik, nem is néznek szembe azzal, hogy az importverseny házhoz" jött. A válaszképtelenség mindjárt részleges magyarázatot jelentett a fentebb bemutatott, viszonylag nagy piacvesztésre is a csak hazai piacra értékesító cégek körében.

Az összkép nem túnik rossznak: a válaszadásra képes vállalatok átlagosan termékeik 58\%-át tartották versenyképesnek a világpiacon, 28\%-ról gondolták úgy, hogy kisebb fejlesztéssel versenyképes lehetne, és csak a kínálat $14 \%$-át tartották esélytelennek a nemzetközi versenyben (4. ábra).

A vállalatméret szerinti csoportosítás eredményei szinte egyenes kapcsolatot mutattak a foglalkoztatottak száma és a versenyképes termékek aránya között. Az egyedi adatokra elvégzett regressziós vizsǵlat azonban ezt a feltéteźst nem igazolta. Logiking azto hogy a kilfüli ́r leketsege hogy a kulfoldi érdekeltsegek rendelkeznek a legnagyobb arányban nemzetközi piacon is versenyképes termékkel, de a lineáris regressziós kapcsolat itt is elég gyenge volt.

A gazdasági ágak szerinti bontás is nagyjából megfelelt az elôzetes elképzeléseinknek. A világpiacon is versenyképes termékek magas aránya a kereskedelemben azt igazolta, hogy az áruforgalom csatornáin ma már valóban szinte minden beérkezik az országba. Érdemes felhívni a figyelmet arra, hogy a szállítás, távközlés csoportban milyen nagy volt azoknak a termékeknek az aŕnya amelyekról a válaszadók úgy gondolták, hogy kisebb fejlesztéssel versenyképes lehetne (5. ábra).$$
\begin{array}{|c|} 
\\
\\
\\
\\
\\
\\
100 \% \\
90 \% \\
80 \% \\
70 \% \\
60 \% \\
50 \% \\
40 \% \\
30 \% \\
20 \% \\
10 \% \\
0 \% \\
\hline
\end{array}
$$

\section{A versenyképes termékek,}

szolgáltatások aránya,

fố nemzetgazdasági ágankén

Forrás: GKI Zrt felmérése
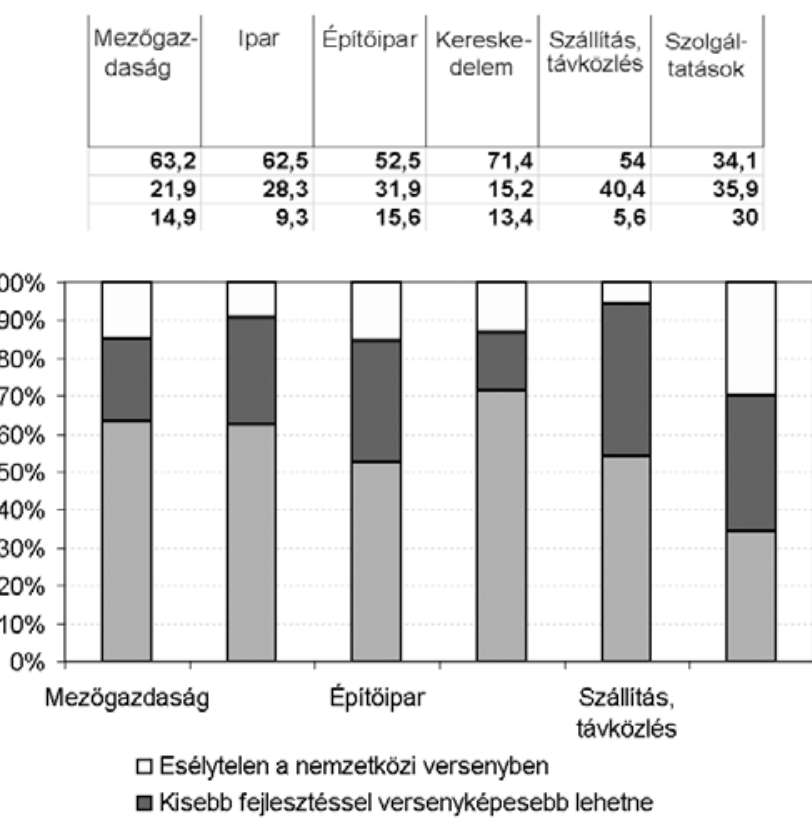

$\square$ A világpiacon is versenyképes 
A belföldi piacra orientált cégek nemcsak kevésbé tudták megítélni kínálatuk nemzetközi versenyképestermékeik felét tartották annak. Nagy exporthányadot versenyképes termékekkel lehet elérni, ez természetes. Figyelemre méltó, hogy a nagy exportórök csoportjá ban volt a legkisebb a némi fejlesztéssel versenykéciálisan versenyképes termékek aránya a belföldre értékesítóknél és a közepes exportőröknél volt nagyobb. A közepes exportőrök erős versenyt jeleztek a pénzügyi források és a munkaeró piacán is, így náluk érthető, hogy miért nem fejlesztik azt, amibôl versenyképes termék lehetne. Nem világos ez az ok a hazai piacra orientált cégeknél.

Meglepóen kicsik az eltérések a verseny erósségének megítélésében a versenyképességi csoportok szerinti bontásban. Az még érthetố, hogy akik jobbára ve senyképes kínálattal szállnak ringbe, azok gyakrabban találkoznak kevés szereplốs piaccal, mint a többiek. De a fordítottját nem láttuk: nem találtunk olyan specialitást a versenyviszonyokban, ami magyarázná, hogy ezek a cégek miért rendelkeznek ilyen nagy arányban világpiacon versenyképes termékkel, szolgáltatásokk (13. táblázat).

13. táblázat

\section{Versenyerôsség}

a legfontosabb piacokon, versenyképesség szerin (megoszlás, százalék) Forrás: GKI Zrt. felmérése

\begin{tabular}{|l|c|c|c|c|}
\hline & $\begin{array}{c}\text { Csak } \\
\text { néhány } \\
\text { szerepló } \\
\text { versenyez }\end{array}$ & $\begin{array}{c}\text { Átlagos } \\
\text { erósségú } \\
\text { a verseny }\end{array}$ & $\begin{array}{c}\text { Kiélezett } \\
\text { a verseny }\end{array}$ & $\begin{array}{c}\text { Durva } \\
\text { a verseny }\end{array}$ \\
\hline 1. csoport & 11 & 29 & 44 & 16 \\
\hline 2. csoport & 6 & 29 & 52 & 13 \\
\hline 3. csoport & 7 & 27 & 46 & 20 \\
\hline 4. csoport & 7 & 22 & 46 & 25 \\
\hline
\end{tabular}

Kissé világosabb a kép, ha a verseny erôsségét és a versenyképes termékek arányát vetjük össze. A vi-
lágpiacon is versenyképes termékek és szolgáltatások lágpiacon is versenyképes termékek és szolgáltatások aránya a legnagyobb az átlagos, illetve a kiélezett ver-r senyrốl beszámolók körében. Lényegében megegyezik ez az arány az oligopol- és a dur

tudósítók esetében (14. táblázat).
A verseny erôssége és a világpiacon is versenyképes termékek aránya között nem sikerült semmiféle elfogadhato linearis kapcsolatot kimutatnunk statisztiségét, de akik válaszoltak, azok is önkritikusan alig pessé tehető termékek aránya, ók nyilván képesek is fejleszteni azt, amit arra érdemesnek tartanak. A poten-

kai eszközökkel. Lazább összefüggés azonban létezik. A 14. táblázat arra utal, hogy sem a verseny gyengesége (csak néhány szereplô versenyez), sem a túl erôs volta (durva a verseny) nem tesz jót a versenyképes termékek piacra vitelének. Különösen tanulságos, hogy a kevés szereplős versenyben a válaszadók viszonylag nagy tartalékkal rendelkeztek versenyképessé tehető termékekbő́l, de nem végzik el az ehhez szükséges fejlesztéseket. Bár egyes ágazatokban ennek lehet többféle magyarázata, nyilvánvaló, hogy a vállalatok csak akkor költenek fejlesztésre, ha ennek szükségét látják, védett, stabilan felosztott piacon nem tesznek erófeszítét, stabilan

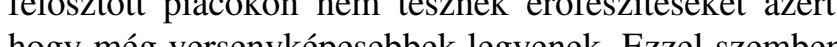
hogy ne a durva, gyakran tisztességtelen verseny kimondottan kedvezóllen a versenyképesség es a fejlesztések szempontjából: a durva versenyt jelzók körében volt a legalacsonyabb a világpiacon versenyképes termékek aránya és legmagasabb a nemzetközi versenyben esélyteleneké. Tapasztalataink indokolttá teszik az állam gazdasági szerepvállalásának ismételt átgondolását. A felmérésból az rajzolódott ki, hogy az állami többségú vállalatok viszonylag védett körülmények között múködnek, alacsony náluk a versenyképes termékek aránya. Ez annak a tankönyvszerú tételnek az igazolása, hogy az állam rossz vállalkozó. Viszont a túl durva - ne szépít sïnk: tisztességtelen, törvénytelen - verseny viszonyi

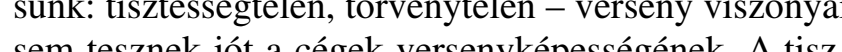
sem tiszek jót a cégek ves tességtelen módzzereket alkalmazó versenytársakka szemben nu a temék án tóbb út. Az állam törvényességi és versenyfelügyeleti tevékenysége érdemben hozzájárulhat a gazdálkodó szektor versenyképességének javításához.

\section{A verseny jellege}

14. táblázat

és a vállalati versenykêsség összefügoése (százalék) Forrás: GKI Zrt. felmérése

\begin{tabular}{|l|c|c|c|c|}
\hline & $\begin{array}{c}\text { Csak } \\
\text { néhány } \\
\text { szerepló } \\
\text { verse- } \\
\text { nyez }\end{array}$ & $\begin{array}{c}\text { Átlagos } \\
\text { erós- } \\
\text { ségú a } \\
\text { verseny }\end{array}$ & $\begin{array}{c}\text { Kiéle- } \\
\text { zett a } \\
\text { verseny }\end{array}$ & $\begin{array}{c}\text { Durva a } \\
\text { verseny }\end{array}$ \\
\hline $\begin{array}{l}\text { A világpiacon is } \\
\text { versenyképes }\end{array}$ & 47 & 65 & 63 & 46 \\
\hline $\begin{array}{l}\text { Kisebb fejlesztéssel } \\
\text { versenyképesebb } \\
\text { lehetne }\end{array}$ & 44 & 24 & 23 & 27 \\
\hline $\begin{array}{l}\text { Esélytelen a } \\
\text { nemzetközi } \\
\text { versenyben }\end{array}$ & 9 & 11 & 14 & 27 \\
\hline Összesen & 100 & 100 & 100 & 100 \\
\hline
\end{tabular}

VEZETÉSTUDOMÁNY

\section{Lábjegyze}

A kutatási program şerződésének száma: AL/28/2007. A kutatásban részt vett a szerzôn kívül: Petz Raymund és Vanicsek Mária

\section{Felhasznált irodalon}

Ahogy a vállalkozások látják..., a GKI Gazdaságkutató $\mathrm{R}$ sorozata, Budapest, 1996-2005.

Aiginger, K. (1995): Creating a dynamically competitive conomy: defining the competitiveness of a nation and a case study. In Devine, P. - Katsoulakos, Y. - Sugden, R. (ends.) (1995): Competitiveness, subsidiarity and ogbjectives, Ruthledge

Antal-Mokos Z. - Balaton K. - Drótos Gy. - Tari E. (1997): Stratégia és szervezet, Közgazdasági és Jogi Kiadó, Budapest

Artner A. (2005): A feldolgozóipar termelési technológia színvonala és a versenyképesség, MTA Világgazdaság Kutatóintézet, Múhelytanulmányok

Bork, R. H. (1978): The Antitrust Paradox. A Policy at War with Itself. The Free Press, New York

Borsi B. (2005): A technológia- és tudásáramlás szerepe magyar feldolgozóipar versenyképességének alakulás ban. EU Tanulmányok II. NFH

Chikán A. - Czakó E. - Lesi M. (2006): Allami szerepválalás a vállalatok versenyképessége nézőpontjából. In: Tanulmányok Magyarország versenyképességérôl. St tratégiai kutatások - Magyarország 2015. 33-61. oldal. Szerk. Vértes András - Viszt Erzsébet. Új Mandátum Könyvkiadó, Budapest

Chikán A. (2001): A versenyképesség koncepcionális háttere és alakulása a XXI. század küszöbén c. 2001. november 6-án tartott tudományos konferencia elóadás-kivonatai. BKE Vállalatgazdaságtan Tanszék

Chikán A. (2005): Vállalatgazdaságtan. 3. átdolgozott, bốvitett kiadás, változatlan utánnyomás. Aula Kiadó, B dapest

Deák Sz. (2000): A Porter-féle rombuszmodell fóbb közgazdasági összefüggései. In: Farkas B. - Lengyel I. (szerk.) Versenyképesség - regionális versenyképessé́g. SZTE Gaz ságtudományi Kar Közleményei. JATEPress, Szeged

Honnan Hová Tanulmányok (2006): MTA-MEH Stratégiaa Kutatások megállapodás keretében került kidolgozásra. Szerk. Viszt Erzsébet

Hovanyi G. (1999): A vallalati versenyképesség makrogazdasági és globális háttere. Michael Porter két modelljenek továbbfejlesztése. Közgazdasági szemle XLVI. év. 1013-1030. o.
Inotai A. (1999): Magyarország és a többi közép- és keleteurópai ország szerkezeti átalakulása a Németországba rányuló export tükrében. MTA VKI-OMFB, Budapest Kapás J. (1998): A vállalati stratégia elméletei, Vezetéstudomány, 11. szám

Karl Heinrich Oppenländer (2002): Business Cycle Survey Data: Definition, Importance, and Application. 26t Clocer sági válś́ MTA KTI kézira sagi alsag. MTA KT, Kezirat

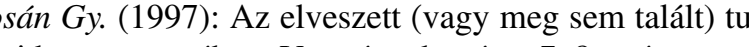
lajdonos nyomában, Vezetéstudomány, 7-8. szám

Got Gazdaság, Vallalkozás, Vezetés, 4 . szám

001): A vállaati várakozási felvétel megbízhatóságáról. Statisztikai Szemle, 9. szám felmérései. Vezetéstudomány, 1. szám

(1997): Milyen jövő́t ígérnek a magyar vállaatok jelenlegi törekvései? Közgazdasági Szemle, 1-2.

etz R. - Zacher L. (1998): Stratégiák, korlátok és törekvések a magyar vállalkozások körében. Gazdaság és Statisztika, június

etz $R$. (1994): A vállalati törekvések (preferenciák) vizsgálatának módszertani alapkérdései. OTKA-kézirat

Mer, (1990): The Competitive Advantage of Nations. Macmillan, London

Porter, M. (1980): Competitive Strategy - Techiques of Analysing Industries and competitors. Free Press, New York. Magyarul: Versenystratégia, iparágak és versenytársak elemzési módszerei. Akadémiai kiadó, Budapest,

Török Á. (1998): A magyar ipar versenyképessége NyugatEurópában I-II. Európa Fórum 1998. (megjelenésre elókészítve, de folyóirat idóközben leállt)

Török Á. (2005): A magyar iparcikkexport versenyképessége Nyugat Európában - Egy lehetséges megközelítés. EU Tanulmányok II. NFH

UNCTAD (2002): World Investment report 2002. Transnational Corportations and Export Competitveness. United Nations New York and Geneva

Várhegyi É. (2003): Bankverseny Magyarországon. Közgazdasági Szemle, L. évf., december, 1027-1048. o

Cikk beérkezett: 2008. 11. hó

Lektori vélemény alapján véglegesítve: 2009. 3. hó 